\title{
Restructuring And Mergers Of The South African Post-Apartheid Tertiary System (1994-2011): A Critical Analysis
}

Nelda Mouton, Ph.D., North-West University, South Africa G.P. Louw, Ph.D., North-West University, South Africa G.L. Strydom, Ph.D., North-West University, South Africa

\begin{abstract}
Socio-economic and vocational needs of communities, governments and individuals change over the years and these discourses served as a compass for restructuring of higher institutions in South Africa from 1994. Before 1994, the claim to legitimacy for government policies in higher education rested on meeting primarily the interests of the white minority. From 1996 onwards, the newly established government considered education a major vehicle of societal transformation. The main objective had been to focus on reducing inequality and fostering internationalisation. Therefore, the rationale for the restructuring of South African universities included a shift from science systems to global science networks. Various challenges are associated with restructuring and include access, diversity, equity and equality. Thus, the restructuring and mergers between former technikons and traditional universities were probably the most difficult to achieve in terms of establishing a common academic platform, as transitional conditions also had to be taken into account and had a twin logic: It was not only the legacy of apartheid that had to be overcome but the incorporation of South Africa into the globalised world was equally important as globalisation transforms the economic, political, social and environmental dimensions of countries and their place in the world. Initially, the post-apartheid higher education transformation started with the founding policy document on higher education, the Report of the National Commission on Higher Education and this report laid the foundation for the 1997 Education White Paper 3 on Higher Education in which a transformed higher education system is described. Restructuring and mergers also had a far-reaching impact, positive and negative, on the various tertiary institutions. This article also reflects on the impact of restructuring and mergers of higher education and reaches the conclusion that higher education faces many more challenges than initially anticipated prior to transformation.
\end{abstract}

Keywords: South Africa; Apartheid; Tertiary Education; Restructuring; Transformation; Neoliberalism

\section{INTRODUCTION}

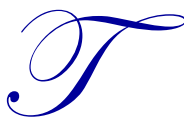

he modern university worldwide has been described as an institution in crisis (Le Grange, 2011). This could be due to the fact that as the socio-economic and vocational needs of communities, governments and individuals change over the years and could also be ascribed to the fact that effective and quality education and training, together with programmes and qualifications and throughput of universities are forced to the foreground (Dill, 2009). Added to this is the reality that, throughout most of South Africa's history, universities have had a conservative reputation with regard to knowledge production and were defensive of established scientific disciplines and programmes (Blunt, 2005; Waghid, 2003; Jansen, 2002). With the enormity of the shift from apartheid to democracy, it is not surprising that any discussion of South Africa's education system would tend to be dominated by the word "transformation" which will imply restructuring and mergers of higher institutions. Thus, few countries can rival South Africa in terms of the complexity of its higher education system and the demands it currently faces for radical, long-term tertiary-sector reform (Elliott, 2005). 
The reasons proposed by the government for the restructuring and mergers in higher education suggest that the mergers were strongly politically and ideologically motivated (Jansen, Habib, Gibbon \& Parekh, 2001; Waghid, 2003) and the reasons can be pin-pointed as follows (Goldman, 2011):

- $\quad$ To overcome the racial fragmentation of the educational system;

- $\quad$ to achieve economies of scale through reducing unit costs and economies of scope;

- $\quad$ to streamline governance and management structures, and to enhance administrative and management capacity;

- $\quad$ to achieve more effective utilisation of existing academic staff capabilities;

- $\quad$ to improve administrative systems;

- $\quad$ to reduce duplication between institutions located close to one another; and

- $\quad$ to improve the quality of programmes offered.

Yet, it was not until 2000 that the new democratic government began to dismantle the old teaching system and started to implement its ideas to reform the South African higher education system (Jansen, 2003). The founding policy document on higher education after apartheid is the report of the National Commission on Higher Education (NCHE) viz., A Framework for Transformation that was produced by 13 commissioners whose terms of reference included advising the Minister on higher education in terms of the types of institutions. On 5 March 2001, the minister released a National Plan for Higher Education (NPHE, 2001) which argued that the number of public higher education institutions in South Africa could and should be reduced (DoE, 2002).

Furthermore, a Ministerial Task Team Report (2001-2007) was appointed to investigate and to report on programme offerings, growth of tertiary institutions, students' success rates, ratio of staff, etc. The recommendations that flowed from this report had influenced higher education dramatically since 2004 and brought about changes over a broad area in the tertiary education sector. In this regard, restructuring was considered as a quick and efficient means of enhancing growth, improving synergy and economies of scale, diversifying and expanding into new markets (Schraeder \& Self, 2003), but it also tended to dilute and spread risk (Papadakis, 2005). Thus, the impact of the restructuring and mergers culminated in the situation where managers and other stakeholders were grappling with the challenges around unlimited growth of student numbers and tertiary institutions and the upkeep of academic standards (Du Plessis, 2011; Eloff, 2009). Restructuring and mergers also included expensive, financial streamlining plans and attempts to eliminate racial diversity, but which in the event actually accentuated racial divisions. In an effort to be relevant, restructuring and mergers accentuated quality and raised the spectre of academic levelling (Elliott, 2005). However, Le Grange (2011) points out that transformation of higher education in South Africa reflects the dismantling of legal apartheid to overcome the legacies of apartheid. Thus, due to historical factors, higher education institutions were highly politicised and extremely sensitive due to the legacy of apartheid (Anon, 2002). This led to significant resistance to what was seen as government interference in higher education and by its very nature, the restructuring process therefore got off to a very emotive start (Tyobeka \& Schoeman, 2007).

\section{AIMS AND OBJECTIVES}

In a country with a diverse population, the perception might be that the tertiary system should be different from what it used to be at the end of the previous millennium in order to address fundamental differences and changes. Therefore, the main aim of this article is to critically analyse the background that led to the restructuring and merging of tertiary institutions, and the impact of this momentous activity on the tertiary system in South Africa.

\section{METHOD AND PROCEDURE}

The above was done by means of a literature review and the findings are presented in narrative format. After critically analysing the process and the impact of the restructuring on some institutions, the researchers identify challenges existing within the tertiary system that will be recommended for further research. The databases used were EBSCO, Sabinet online, journals, books and various newspapers. They keywords included: Merger, restructuring, universities, tertiary education, apartheid, neoliberalism and transformation. 


\section{BACKGROUND AND HISTORICAL OVERVIEW OF HIGHER EDUCATION IN SOUTH AFRICA UNTIL 1994}

Before 1994, there was a persistent perception that black universities were being deliberately poorly funded by the apartheid regime (Khoza, 2009). In this section it is deemed necessary to explore the history of tertiary education in South Africa, the rationale and process for restructuring and mergers, and models that could have inspired the fundamentally radical restructuring and merger process in the country.

\subsection{A summarized historical overview of the development of tertiary institutions in South Africa}

Before 1994, the claim to legitimacy for government policies in higher education rested on meeting the interests of the white minority. Therefore, governance arrangements directed student participation, resource allocations and research funding (Hall \& Symes, 2005).

Since the 1850s, white people in South Africa had access to higher education through earning degrees and other qualifications from the University of London. In 1873, the colonial government established the University of the Cape of Good Hope (UCGH) in Cape Town, which was modelled on the University of London with its own Chancellor, Vice-Chancellor and Registrar (Metcalfe, 2008). In 1915, Scottish missionaries established a formal post-secondary college, later known as the University of Fort Hare, to train black people as pastors, teachers and some industrial professions. It has been argued that the government of the time had agreed to its establishment as one way to gain the support of African people during World War I, rather than as a sincere effort to provide university education (Metcalfe, 2008). The missionaries maintained tight control over the curriculum and did not appoint black teaching staff. Students came from all over Africa to study at this college, and this influx of students was ascribed to the lack of post-secondary education elsewhere in Africa.

In 1916, the government passed the Higher Education Act, which brought all university colleges under the control of the Ministry of Education. The University of South Africa (UNISA), with its seat in Pretoria, replaced the UCGH. The colleges remained affiliates of UNISA until they could meet the criteria for full university status, for example, in 1918, the South African College became the University of Cape Town and Victoria College became the University of Stellenbosch (Metcalfe, 2008). In 1921, the South African School of Mines and Technology became the University of the Witwatersrand in Johannesburg and the Transvaal University College became the University of Pretoria in 1930.

The trinarian model proposed by the Van Wyk De Vries Commission of Inquiry into universities in 1974 maintained that universities should concentrate on the teaching and research of the basic fundamental principles of science, that technikons should concentrate on the application of scientific principles to practical problems and on technology. Furthermore, colleges also had to provide vocational training (Kraak, 2001). In short, Van Wyk De Vries was arguing that the business of universities was to induct students into the canonical principles of disciplinary-based sciences via Bachelors', Masters' and Doctoral degree programmes (Kraak, 2001).

The newly-established government following the change to a democracy dispensation in South Africa and charged with the highly volatile education portfolio, considered education to be a major vehicle of societal transformation (Kampsteeg, 2008). Critical debates were initiated in 1990 when South African political life was normalised with the unbanning of political movements (Hall \& Symes, 2005) and South Africa's higher education history entered an era of turmoil (Jansen, 2003). Many believed that the post-1994 higher education sector would be shaped around the model of the liberal South African university with a high degree of institutional autonomy (Hall \& Symes, 2005).

From the outset the ANC-led government adopted an interventionist approach, directed specifically at educational change. The objective of this approach was to focus on reducing inequality and fostering internationalisation (Kampsteeg, 2008). The increased demand for tertiary and vocational training in the new postapartheid education scenario brought a whole new package of other problems as well. In this regard Hall and Symes (2005) proposed conditional autonomy where the state recognises the role in steering the system and its outcomes 
through procedural controls, while respecting the autonomy of individual institutions in the substantive field of their intellectual work.

In 1994 there were five identifiable but overlapping phases that need mentioning (Kraak, 2001):

1. The pre-"taking of power" phase - By 1989 the politics of the anti-apartheid movement had shifted from mass struggle to "preparing to govern".

2. The legislative era - The period 1994-1997 witnessed significant education legislation being enacted by Parliament, culminating in the passing of the Higher Education Act (1997).

3. The policy implementation phase - This period overlaps with the legislative era, but became amplified after the passing of the Higher Education Act (1997). It was a period when the limits of state power began to surface and when policy idealism in education was inevitably mediated by the structural constraints and political limits facing the new state.

4. A vacillating state, the era of policy doubt and retraction - The complexities of governance in the new state began to emerge, particularly in the period 1999-2000, when the Council on Higher Education's (CHE) Task Team deliberated on issues such as the size and shape of institutions. During this period the discursive tensions and political difficulties reached a high point, resulting in significant policy doubt and retraction.

5. The National Plan, February 2001 - The release of this policy documents sees the state reaffirming its support for the key policy principles contained in the Higher Education Act (1997) and a new determination to implement them was noticed. Unfortunately, policy ambiguity and slippage were the key outcomes of this circular interplay between discourse, state power and history during this phase.

\subsection{Rationale for the restructuring and merging of South African Universities}

The restructuring of the higher education system was one of the measures used by the Department of Education to transform the higher education section (Qhobela, 2009). Thus, restructuring proposals have become a central part of South African higher education policy and therefore getting them "right" was an important priority. Harman and Meek (2002) state that the restructuring of tertiary institutions could take any number of different forms - from loose affiliations at one end of the spectrum to tightly integrated models at the other (Elliott, 2005). The goals included bridging the apartheid-induced divide between historically white and historically black institutions as well as enhancing the efficient use of resources and improving institutional responses to national and regional needs (Qhobela, 2009). Major hurdles regarding the merging process at most institutions in South Africa included resistance to change and low levels of trust (Eloff, 2009). The transformative character of the restructuring had radical implications as it was designed and implemented in a context of political transition which made it a unique and a highly hazardous operation (Kampsteeg, 2008). The question that should have been asked prior the merging process includes the effects institutional mergers would have on the quality and diversity of South African universities (Elliott, 2005) as the historically disadvantaged universities in South Africa appeared ill-equipped to become viable and efficient higher education institutions. This would require substantial investment in these institutions and could include possible conversions or closure of weak institutions (Kraak \& Young, 2001). This also included the closing down of teachers' and nursing training colleges (Harper, 2011).

Restructuring might be understood as a process that has no beginning and no end (Le Grange, 2011). In this context it is a term that is used with reference to changes that the modern university is undergoing in a rapidly globalising world. Various challenges are associated with restructuring and include access, diversity, equity and equality (Le Grange, 2011). The origins, forms, and outcomes of restructuring are conditioned by, and contingent on, the specific forms of interaction between institutional micro-politics and governmental macro-politics, especially in turbulent or transitional contexts (Sehoole, 2005). The higher education system inherited by the first democratically elected South African government in 1994 was characterised by multiple divisions. In the South African context one of the major stumbling blocks to successful mergers in higher education is the fraught historical-political aspect. Besides being politically motivated, there was also another motivation for the restructuring of institutions and that was the need to incorporate the South African higher education system within fast-changing, technology-driven and information-based economies described under the rubric of globalization 
(Sehoole, 2005; Jansen, 2001). An amount of R3 billion was therefore budgeted to support the restructuring process and by 2009, all these funds had been used as intended (Qhobela, 2009).

Restructuring and mergers between former technikons and traditional universities were probably the most difficult to achieve in terms of establishing a common academic platform (Tyobeka \& Schoeman, 2007). Transformation also includes the integration of academic labour into the industrial economy. This element relates to the idea that contemporary society is a knowledge society that is increasingly being driven by a knowledge economy.

It is important that transitional conditions for restructuring should also be taken into account and it includes the following (Jansen, 2003):

- $\quad$ A system deeply marked by racial inequalities (among both staff and students);

- $\quad$ universities and technikons that suffered serious governance and management crises;

- unequal student enrolment, as a consequence of which the better (white) institutions received the good students and the formerly black institutions the poor students; and

- $\quad$ a chronic fragmentation and huge imbalances countrywide that reflected the former apartheid government's goals and strategies where the black institutions were mainly but not exclusively located in marginal rural areas.

The transition process of tertiary institutions in South Africa also had a twin logic: It was not just the legacy of apartheid that was to be overcome but incorporating South Africa into the globalised world was equally important (Kampsteeg, 2008).

According to Jansen (2004) there is a multitude of changes that have transformed higher education in South Africa. The ten most important changes in higher education include the size and shape, meaning of autonomy and accountability, the nature of higher education, character of student distribution, management and governance, roles of student politics, models of delivery, the notion of higher education between free trade and public good, programme changes and the nature of the academic workplace (Jansen, 2004).

\subsection{The process of restructuring and merging of higher institutions}

Post-apartheid higher education transformation started with the founding policy document on higher education, the Report of the National Commission on Higher Education (NCHE) entitled A framework for transformation (1996) (Mfusi, 2004). In this regard, the key recommendation of the NCHE was that higher education in South Africa should be conceptualised, planned, governed and funded as a single co-ordinated system. The need for such a proposal arose because of what the Commission perceived to be an absence of any sense of system in South African higher education. Three major deficiencies were noted, viz:

- There was a chronic mismatch between higher education's output and the needs of a modernising economy;

- There was a strong inclination towards closed-system, disciplinary and programmes approach, which led to inadequately contextualised teaching and research. The content of the knowledge produced and disseminated was insufficiently responsive to the problems and needs of the African continent, the Southern African region and the vast numbers of poor and rural people in our society; and

- There was a lack of regulatory frameworks, due to a long history of organisational and administrative fragmentation and weak accountability (Kraak, 2001).

This report laid the foundation for the 1997 Education White Paper 3 on higher education named $A$ programme for the transformation of higher education (Mfusi, 2004). This report describes a transformed higher education system as one of which will (Boughey, 2004):

- $\quad$ provide equal access and equally fair chances of success to all students; 
- $\quad$ develop programmes leading to qualifications that will meet the country's employment's needs in respect of highly skilled graduates;

- $\quad$ promote critical and creative thinking, tolerance and a commitment to the common good through its teaching; and

- $\quad$ produce research of an international standard that, at the same time, will be cognisant of African contexts.

The objectives of White Paper 3 state that higher education would need to address problems of equity, redress, democracy, autonomy and efficiency (Elliott, 2005). The CHE released a document Towards a new high education landscape: Meeting the equity, quality and social development imperatives of South Africa in the $21^{\text {st }}$ century in 2000 (Mfusi, 2004). The NPHE (2001) addresses five key policy goals and objectives to deliver on in the context of the transformation of higher education:

- $\quad$ To provide increased access to higher education to all, irrespective of race, gender, age, creed, class or disability and to produce graduates with the skills and competencies necessary to meet the human resource needs of the country;

- $\quad$ to promote equity of access and to redress past inequalities through ensuring that the staff and student profiles in higher education progressively reflect the demographic realities of South African society;

- to ensure diversity in the organisational form and institutional landscape of the higher education system through mission and programme differentiation;

- $\quad$ to build high level research capacity to address the research and knowledge need of South Africa; and

- to build new institutional and organisation forms and new institutional identities through regional collaboration between institutions (NPHE, 2001).

In 2002 the Department of Education published a document entitled Transformation and Restructuring: A New Institutional Landscape for Higher Education (DoE, 2002) which outlined the intended rationalisation of the sector. The clustering recommended in the report reduced the number of higher education institutions in South Africa from 36 to 23 and in January 2005 all of the mergers were legally enacted (Du Plessis \& Lodewyckx, 2007).

The 1997 Higher Education Act provided the Minister with a number of instruments with which to steer the tertiary sector. The major consultative mechanism is the Council on Higher Education. Hall and Symes (2005) state that the Minister determines, in consultation with the Council on Higher Education (and with the concurrence of the Minister of Finance), policy on the funding of public higher education and allocates public funds to public higher education (RSA, 1997, Section 39). Furthermore, The Higher Education Act 101 of 1997 (Section 23), also indicates that the Minister may, after consulting the Council on Higher Education (CHE) and by notice in the Gazette, merge two or more public higher education institutions into a single public higher education institution (May \& Mason, 2007). In order to achieve the goals of a single higher education system that would contribute to reconstruction and development, the NPHE announced sixteen outcomes described as "system-wide targets and goals" to be achieved through "steering mechanisms" such as setting "benchmarks" to increase graduate outputs, establishing a student financial aids scheme to ensure that academically able students who do not have the financial resources are not prevent from pursuing higher education studies and providing postgraduate scholarships targeted at black, women and disabled students (Waghid, 2003). The aim of the NPHE (2001) was as follows:

- The participation rate in higher education should be increased from 15\% - 20\% within 10-15 years. This meant that there should be improvement of throughput from the school system in numbers and quality;

- $\quad$ the balance of enrolments should be shifted away from the humanities towards Business and Commerce, Science, Technology and Engineering. Some ways in which this could be strengthened are by improving the quality of Mathematics teaching, increasing the number of students matriculating with Mathematics and Science and restructuring curricula to provide the skills and qualities for employment purposes, particularly increasing enrolments in information and communications technology;

- $\quad$ institutions should increase graduate outputs from 90000 to 100000 per annum;

- $\quad$ institutions should increase recruitment of students from the South African Development Community (SADC) especially at the post-graduate level; 
- $\quad$ institutions should enhance cognitive skills of graduates by equipping all graduates with the skills and qualities required for participation as citizens in a democratic society and as workers and professional in the economy;

- $\quad$ institutions should develop distance missions and academic programme profiles in order to ensure diversity within the system;

- $\quad$ the academic Programme and Qualifications Mix (PQM) at each institution should be determined by current programmes and a demonstrated capacity to offer new programmes;

- $\quad$ the technikon-university distinction should be maintained for at least five years; and

- $\quad$ redress for historically black institutions should be linked to agreed missions and programme profiles (Boughey, 2004,Waghid, 2003).

\subsection{Models for change}

Du Plessis and Lodewyckx (2007) indicate that models for change can be either weak or strong. Weak forced change is where the partners of institutions retain their original identities. A strong forced change is where a constituent organisation retains limited independent identity and where strategic interdependence is high. The latter also links with the concept of full absorption/forced change with pressure to assume a unitary institutional identity. The outcomes of the mergers, either way, have been disappointing in many ways:

- The altered size and shape of the higher education system has not resulted in dramatic increases in black graduates in key field such as engineering and medicine. Across the board, the success rate of students doing a three-year bachelor's degree through contact mode is only $22.5 \%$ (Le Grange, 2011). Thus, the final discursive influence is that of stratification thinking. This is a residual discourse and a contemporary expression of a much older discourse that has strong roots in the education policies of the previous government (Kraak, 2001). Due to this thinking, it could be argued that many of the existing problems within higher education are there precisely because of this process of thinking.

- It should be noted that while policy and legislation established the Minister as head of the system of higher education governance, linkage between autonomous institutions and the state does not take the form of direct accountability to the minister. University and Technikon Councils, as the supreme governing bodies of institutions, are accountable more broadly to civil society and Councils retain their linkage to the state mainly through their fiduciary role (Hall \& Symes, 2005).

- $\quad$ After considering background factors that influenced the restructuring and mergers of higher institutions in South Africa it is therefore deemed crucial to analyse the impact of the restructuring and mergers of institutions in the South African setting.

Hall and Symes (2005) argue that under the apartheid regime, the relationship between individual institutions and the state had varied considerably Whereas constant expansion and an uncontrolled proliferation of institutions (along racial lines) were the norm, the restructuring brought about a significant consolidation in the number of institutions and a total transformation in their form and function (Tyobeka \& Schoeman, 2007). Part of the rationale for change was to create new institutions with new identities and much focus was placed on the macroimplication of changes (Du Plessis \& Lodewyckx, 2007). Table 1 will indicate the former higher institutions and the institutions after the merger process. This is included to form a better understanding of the discussions to follow (Kampsteeg, 2008). 
Table 1: A comparison between current universities and former tertiary institutions

\begin{tabular}{|c|c|}
\hline Current Universities & Former Tertiary Institutions \\
\hline \multicolumn{2}{|l|}{ Traditional Universities } \\
\hline \multicolumn{2}{|l|}{ University of Cape Town } \\
\hline \multicolumn{2}{|l|}{ University of Fort Hare } \\
\hline University of the Free State & Incorporation of part of Vista University \\
\hline University of KwaZulu-Natal & $\begin{array}{l}\text { University of Durban-Westville } \\
\text { University of Natal }\end{array}$ \\
\hline University of Limpopo & $\begin{array}{l}\text { Medical University of South Africa (MEDUNSA) } \\
\text { University of the North }\end{array}$ \\
\hline North-West University & $\begin{array}{l}\text { University of North-West (UNIBO) } \\
\text { Potchefstroom University for Christian Higher Education }\end{array}$ \\
\hline University of Pretoria & Incorporation of part of Vista University \\
\hline \multicolumn{2}{|l|}{ Rhodes University } \\
\hline \multicolumn{2}{|l|}{ University of Stellenbosch } \\
\hline \multicolumn{2}{|l|}{ University of the Western Cape } \\
\hline \multicolumn{2}{|l|}{ University of the Witwatersrand } \\
\hline \multicolumn{2}{|l|}{ Comprehensive Universities } \\
\hline University of Johannesburg & $\begin{array}{l}\text { Rand Afrikaans University } \\
\text { Technikon Witwatersrand } \\
\text { Incorporation of part of Vista University }\end{array}$ \\
\hline Nelson Mandela Metropolitan University & $\begin{array}{l}\text { University of Port Elizabeth } \\
\text { Port Elizabeth Technikon } \\
\text { Incorporation of part of Vista University }\end{array}$ \\
\hline University of South Africa & $\begin{array}{l}\text { Technikon SA } \\
\text { Incorporation of part of Vista University }\end{array}$ \\
\hline \multicolumn{2}{|l|}{ University of Venda } \\
\hline Walter Sisulu University for Technology and Science & $\begin{array}{l}\text { Border Technikon } \\
\text { Eastern Cape Technikon } \\
\text { University of Transkei }\end{array}$ \\
\hline \multicolumn{2}{|l|}{ University of Zululand } \\
\hline \multicolumn{2}{|l|}{ Universities Of Technology } \\
\hline \multicolumn{2}{|l|}{ Cape Peninsula University of Technology } \\
\hline \multicolumn{2}{|l|}{ Central University of Technology } \\
\hline \multicolumn{2}{|l|}{ Durban University of Technology } \\
\hline \multicolumn{2}{|l|}{ Mangosuthu Technicon } \\
\hline \multicolumn{2}{|l|}{ Tshwane University of Technology } \\
\hline Vaal University of Technology & $\begin{array}{l}\text { Incorporation of part of Vista University and NWU absorbed } \\
\text { Vista students and staff }\end{array}$ \\
\hline
\end{tabular}

From 1999 onwards some institutions began to merge as instructed by the Minister of Education and as it had been stated in the Higher Education Act of 1997 (Mfusi, 2004). These mergers were mostly incorporations by universities of former teachers training colleges and so forth. Thus, in a relatively short period of time the higher and further education landscape in South Africa altered dramatically: 21 Universities became 11 institutions, 15 technikons became five "stand alone" technikons and 6 comprehensive institutions (combinations of universities and technikons); 150 technical colleges became 50 merged technical colleges and 120 colleges of education eventually became only two colleges of education with the rest either incorporated into universities or technikons. At the start of 1998, colleges were being incorporated into universities and technikons. At the same time, the merger of universities and technikons had been finalised after an intensive political process. In 2004, South Africa started reforming its higher education system, merging and incorporating small universities into larger institutions, and renaming all higher education institutions "universities". The restructuring also introduced comprehensive universities, a new type of institution designed to cater for the merger of some universities with former technikons. Comprehensive universities offer a broad range of degrees, diplomas and certificates, and help widen access to tertiary education in the country. Thus, 306 separate institutions for post-school education were radically reduced to 72 remaining institutions - not counting the on-going restructuring of nursing and agricultural colleges (Jansen, 2004). 
As of 18 February 2011, there were also 87 registered and 27 provisionally registered private higher education institutions. The report of the national working group on higher education, which was made public early in 2002, recommended a number of institutional mergers. By 1 January 2004 the gearing-up phase was completed and the consultative phase was about to commence. A host of merger structures and forums were created in 2003 and 2004 (Goldman, 2011). In this regard, the Joint Merger Steering Committee (JMSC) was the highest authority for merger issues and had the authority to make binding decisions (Goldman, 2011). Having considered these recommendations, the Minister of Education then made a proposal regarding the restructuring of the system that was approved by the South African Cabinet and made public in May 2002. As a result of the restructuring process, the number of higher education institutions was initially reduced from 36 to 21 (Elliott, 2005). Unlike business-oriented mergers where the merging partners generally harbour an expectation of improved functioning and enter the merger with a degree of willingness, the merging parties in most of these enforced mergers were substantially unwilling merger partners and should these mergers have gone awry they could not be resolved through subsequent outsourcing of business operation (Goldman, 2011). Also, mergers between academic institutions are more complex and difficult to achieve than mergers in the business sector. Whereas the latter focus almost exclusively on enhancing business and financial outcomes, mergers in public higher education happen in the realm of public opinion and necessitate extensive consultation with a myriad of stakeholders and opinion leaders (Tyobeke \& Schoeman, 2007).

\section{THE IMPACT OF RESTRUCTURING AND MERGERS ON SELECTED TERTIARY INSTITUTIONS}

When analysing the restructuring of tertiary institutions in South Africa it is clear that merger origins and ends cannot be stated or proclaimed outside of the interactional effects of what happens inside institutions (universities and colleges) and what happens outside of institutions (national and provincial governments) (Sehoole, 2005). This perspective indicates that uniform outcomes are predicted for mergers based on some predetermined list of "ingredients" for merger success (Goedegebuure, 1992). Thus, theoretical orientation assumes that organisations are rational, but in South Africa institutions resisted mergers even when the available evidence suggested greater benefits for both institutions and society in the context of resources being shared, expertise consolidated and deficits reduced (Sehoole, 2005). The validity for restructuring was to make the system more efficient and to reduce wastage as a result of duplication of programmes (Le Grange, 2011). At the same time, institutions also wanted to keep their own identities (Sangotsha, 2008). But, the last thing that any institutional management would want is to see that their top academics find employment at other institutions while the university finds itself in the midst of disruptive change (Goldman, 2011). Merit objectives clashed with goals of access and equity. For example, two questions were asked by Elliott (2005) if the University of Fort Hare, with its relatively minor academic reputation but prominent history as a training ground for ANC leaders, were to be integrated with other institutions to create an academically stronger, but politically and symbolically weaker university. Secondly, he (Elliott, 2005) questioned whether even if cross-racial mergers successfully ran a political gauntlet, how much access to newly integrated institutions would really improve if the same programmes that targeted minority populations thereby stigmatised them as being in need of targeting. Successful incorporations include the University of the Western Cape (UWC) and the University of Stellenbosch (US) where they agreed to establish a single faculty of dentistry in the Western Cape (Qhobela, 2009).

Many merged institutions have separate campuses that mainly still function as separate units. An example is the North-West University (NWU), where the Mafikeng Campus is mainly black and the medium of instruction predominantly English, whereas the Potchefstroom Campus is mainly white and the language of instruction predominantly Afrikaans (with educational interpreting in niche programmes in order to ease access) (Le Grange, 2011). Mafikeng is the capital of the North-West Province and houses an almost totally black rural area which has a limited academic tradition. The smallest of the three NWU campuses, based in the Vaal Triangle, has a mixed staff and student population and had long been a Potchefstroom satellite campus. Mafikeng Campus was also subjected to a ministerial committee investigation in 2008 due to dissatisfaction with the merger (Qhobela, 2009). The Potchefstroom Campus remains the NWU's dominant campus and it hosts the hub of administration, known as the Institutional Office (Kampsteeg, 2008). The then Minister of Education, Pandor ,indicated that she was impressed by the statistics provided by the NWU, but expressed doubts about whether the NWU was really a merged institution, given the three distanced campuses (Qhobela, 2009). It would also seem that other merged institutions in the country inevitably have similar issues that need to be addressed (Kampsteeg, 2008). 
Cohen (2006) indicates that the Nelson Mandela Metropolitan University was threatened with legal action, several resignations, and dissatisfaction by staff as they had to re-apply for their posts.

A study was conducted by Goldman (2011) where the merger of the Rand Afrikaans University (RAU) with the Technikon Witwatersrand (TWR) indicated that the way individuals perceived the merging had a definite impact on their level of job satisfaction. Those who were negatively predisposed toward their historic institution were less satisfied with their jobs than those with positive predispositions (Goldman, 2011).

In the case of the merger of Durban University of Technology it was felt that the goals were not clearly stipulated (May \& Mason, 2007). Weber and Weber (2001) state that goal clarity is the degree to which employees comprehend organisational goals. May and Mason (2007) concur and indicate that trust in management and perceptions of organisation readiness for change need specific attention during any transformation to assist in success.

In the case of Tshwane University of Technology (TUT), the merger of the three former technikons at the beginning of 2004 presented the first decisive move away from the former system. Transformation was aimed at consolidating higher education and this would do away with differences in higher education resourcing. Tyobeka and Schoeman (2007) indicate that it also meant that the infrastructural and other discrepancies in the system were to be addressed systematically as part of a national process that cut across the entire higher education spectrum. They (Tyobeka \& Schoeman, 2007) confess that the TUT merger was an unequal one that brought together three fundamentally different institutions. In terms of infrastructure and service delivery at the various teaching and learning sites, expectations were raised that equity would result almost immediately and they feel that the Department of Education (DoE) did not provide the financial means to support the process from the start, thus dooming it to a certain extent. This merger was a complicated task as the three technikons to be merged had their own management styles and salary structures (Magome, 2009). TUT also regards the renaming of technikons as universities of technology as a new broader mandate to develop in specialised areas with the academic debate leading to the conclusion that much greater emphasis should be placed on producing quality products for the world of work as well as future leaders for society (Tyobeka \& Schoeman, 2007).

It was also noted that institutions with strong leadership, participatory and inclusive management were able to navigate the mergers more successfully than others (Qhobela, 2009).

\section{THE EDUCATION PROCESS AND OUTCOMES OF RESTRUCTURING AND MERGERS ON TERTIARY EDUCATION}

When mergers took place, changing curriculum implications became a reality. Mfusi (2004) states that some institutions had more to lose than to gain from mergers in as far as the curriculum was concerned. The policy documents that steered the merging process are silent about what should happen to the curricula (Mfusi, 2004). It is also essential that the logic that continues to perpetuate inequalities needs to be revisited and critiqued (Seepe \& Lansink, 2010). Therefore, this section will reflect on the impact that restructuring had on organizational orientation, the impact on programme offerings and Mode 2 knowledge production as well as the influence of neoliberalist thinking.

\subsection{Organizational orientation}

After the 1994 election, that symbolically ended apartheid, higher education in a new South Africa found itself with a number of challenges as quality differed markedly across both racial and geographic lines. Rural and traditionally black institutions, such as Fort Hare, were far behind the internationally prominent white universities of Cape Town or Witwatersrand in funding, facilities and international reputation (Elliott, 2005).

From 1993-1997 student numbers increased (Elliott, 2005) but, matriculation levels decreased. Explanations include a reduction in the number of secondary exemption certificates, the growth of private higher education providers and displacement effects that shift matriculants from one institutional subsector to another (Jansen, 2001). 
It is also important that employment strategies in a merged institution should facilitate a positive morale amongst a diversified staff component that will lead to institution building (Draai \& Theron, 2007). According to Ramphele (1994), the lack of transformation of academic and management profiles is a common phenomenon of historically white tertiary institutions. For example, the University of Pretoria (UP) came under attack in 2002 for lack of transformation of its academic and management profile (Majola, 2002). Ramphele (1994) points out that gender inequalities exist in these institutions because women are found predominantly in junior ranks and few reach higher academic ranks (associate professor and professor). Although controversial, the South African Students Congress (SASCO) called for the disbanding of the University of the Free State Council due to a too slow transformation process (Modjadji, 2011). On the other hand Jansen (vice-chancellor of the University of the Free State) doubled the number of black professors and promoted several black people to senior administrative positions. UFS also now has 30000 students of whom 65\% are black (Blaine, 2010).

Infrastructural integration is the most complex, messy and drawn-out component of mergers in transitional contexts (Sehoole, 2005). The real discrepancies in resource allocation and infrastructural development made for an uncomfortable fit. Tyobeka and Schoeman (2007) reflect that it required a total mind shift of the participants who had to accept and equality was not borne out by the evidence around them.

It goes without saying that mergers also created a global concern, particularly for the more academically prominent universities that had developed international networks of scholarship and (less frequently) funding before 1994 (Elliott, 2005). Tyobeka and Schoeman (2007) indicate that there is a lot of scope in creating international opportunities for co-operation and knowledge exchange internationally.

Furthermore, some of South Africa's universities (e.g. the University of Cape Town, the University of Stellenbosch and the University of Pretoria) are world-class academic institutions at the cutting edge of research in various spheres. Together the country's 21 public higher education institutions offer a range of study and research options for both local and international students. Although partially subsidised by the state, South Africa's universities are autonomous, reporting to their own councils rather than to government (Jansen, 2004).

It is also important to note that despite in-depth studies, consultations and policies de-mergers of some institutions have also been suggested. In this regard, SASCO has welcomed the de-merger of the University of Limpopo (Modjadji, 2011). It has been felt very widely that this merger was ill-informed and it was therefore suggested by the Minister of Higher Education and Training, Min. Nzimande and Health Minister, Min. Motsoaledi that the medical campus, Medunsa, should be expanded and demerged (Gernetzky, 2011; Harper, 2011; Monama, 2010).

Although intentions to merge institutions were well-researched, they had an immense impact of good and bad financial administration processes. As an outflow of the impact of restructuring and mergers, five institutions are under administration. These include the Tshwane University of Technology (TUT), Walter Sisulu University (WSU), Vaal University of Technology (VUT), the Central University of Technology (CUT) and the University of Zululand (Skiti, 2011a). This resulted in the university (WSU) could not afford to pay their R68 million monthly salary bill (Skiti, 2011a) and are facing possible retrenchments (Skiti, 2011b). The WSU is technically bankrupt (Kgosana \& Mokone, 2011). Minister Nzimandi appointed an independent assessor to report on the affairs of the Central University of Technology (CUT) after he received complaints about poor governance and financial mismanagement (Macupe, 2012).

\subsection{The impact of programme offerings and Mode 2 knowledge production}

The International Alliance for Invitational Education was founded in 1982 by a group of educators and supporters of the education profession throughout the United States and Canada on the campus of Lehigh University (IAIE, 2002). It consists of five components (viz. ecosystem, elements, level of functioning, cornerstones and messages) within a specific teaching environment which is known as the invitational teaching ecosystem. The latter includes places, people, policy, programmes and processes (Du Plessis \& Lodewyckx, 2007). 
Places consist of physical layout and environment where the institution is located. Shortcomings can transmit negative messages. The physical environment should communicate trust, respect, optimism and intentionality. Rooms, offices and facilities should testify to functionality, enchantment, cleanliness, efficiency and aesthetic, personal and invitational space (Du Plessis \& Lodewyckx, 2007). The challenge faced is the fact that a limited degree of organisational integration characterised the mergers in South Africa (Jansen, 2005).

Educators and students as people are the creators of various learning theories and approaches. The impact of mergers on staff has been devastating for the emotional and professional lives of educators (Jansen, 2005). The impact of mergers on academic staff has negatively influenced an invitational ecosystem (Du Plessis \& Lodewyckx, 2007). Jansen (2004) notes that people felt threatened by the merger actions and revealed feelings of insecurity by refusal to participate.

In the practice of teaching, the educator is often confronted with policies that do not reflect the elements of invitational teaching (Purkey \& Schmidt, 1990) and in this regard Jansen (2004) has indicated reluctance on the part of some educators to merge pedagogic imperatives with course content requirements.

The fourth component refers to programme offering which should focus on the wider needs from the macro-level to the micro- level in order for the community and individual to benefit appropriately (Purkey \& Schmidt, 1990). The educational transactions that followed the physical reorganisation impacted immensely on programme offerings (Du Plessis \& Lodewyckx, 2007). Jansen (2004) envisaged that the establishment of new institutional cultures would largely depend on the curricula that would emerge from the merger process.

Lastly, processes represent content and context. Invitation processes deal with the functioning of the educator, property, layout and equipment, policy and programmes. Du Plessis and Lodewyckx (2007) elaborate that processes can include academic orientation, grouping, networking, skills, democratic character, co-operation, procedures, interaction, assessment and opportunities.

Jansen (2002) points out that South African higher education policy documents after 1994 bear the fingerprints of Gibbons' theory on knowledge production. Le Grange (2011) strengthens this notion by acknowledging that some of Gibbons' colleagues, such as Peter Scott, served as consultants for higher education policy development in the post-apartheid South Africa. Jansen (2002) continues his argument by stating that the accommodation of Mode 2 knowledge production in South African universities is uneven. But, how does knowledge production happen and what is meant by knowledge production? There are two acknowledged modes of knowledge production - Mode 1 and Mode 2 where there has been transformation from Mode 1 to Mode 2 knowledge production (Ondari-Okemwa, 2011). Mode 2 knowledge production is context-driven, problem-focused and interdisciplinary. It involves multidisciplinary teams brought together for short periods of time to work on specific problems in the real world. Mode 1 is linear and almost exclusively academic, investigator orientated and discipline-based whereas Mode 2 is non-linear and reflexive in orientation (Ondari-Okemwa, 2011). Therefore, while Mode 2 knowledge forms are expanding at the University of Pretoria (UP), there is little evidence of its success in a historically disadvantaged university such as the former University of Durban-Westville. In this regard Du Plessis and Lodewyckx (2007) reiterate that the offering of programmes at multiple sites of delivery that have different resources and staff compositions is recognised. Also, very little has been done to determine the effect thereof on the learning process and the experiences of students at the institution. Mode 2 knowledge production is of vital importance as it will have a direct influence on teaching/learning programmes and the organisational and design features thereof (Le Grange, 2011). With regard to the first mentioned, several universities have abandoned traditional academic departments and replaced them with programme directors and schools. Also, larger structures are organised around programmes and not disciplines. In terms of design features, on the other hand, there has been a shift in programme design in the sense that academic disciplines do not necessarily inform the goals and visions of programmes, but instead the outcomes. Le Grange (2011) continues his argument by stressing that these outcomes are linked to the need of both global and South African societies. Thus, the approach to curriculum design is one of "design down, deliver up", where modules now have to be redesigned in the service of the vision and outcomes of a programme. The implication is that Mode 2 knowledge production concerns a shift in the way knowledge is produced in a socially distributed knowledge system. It does not only relate to the production of knowledge, but 
also to its transmission and acquisition, in the sense that knowledge included in teaching programmes becomes reframed (Le Grange, 2011).

Mode 2 knowledge production will have an effect on research in the $21^{\text {st }}$ century as it will introduce a paradigm shift for researchers (Hay, 2000). This can be illustrated as follow:

Table 2: A comparison between the "old" and "new" paradigms

\begin{tabular}{|c|c|}
\hline "Old" Paradigm & "New" Paradigm \\
\hline High-mindedness - knowledge/research for its own sake & Service orientation, research to support the economy \\
\hline Theoretical approach & Pragmatic approach \\
\hline Academic autonomy / academic freedom & Quality orientation: Value for money and accountability \\
\hline Universities should cultivate intellect & $\begin{array}{l}\text { Broader and coherent intellectual culture / global intellectual } \\
\text { culture }\end{array}$ \\
\hline $\begin{array}{l}\text { Mode } 1 \text { Knowledge production / research } \\
\text { - Disciplinary bound: Problems researched and solved in a } \\
\text { context governed by (largely academic) interests of a } \\
\text { specific community } \\
\text { - Homogeneity of research skills } \\
\text { - Curiosity-driven } \\
\text { - Free inquiry }\end{array}$ & $\begin{array}{l}\text { Mode } 2 \text { Knowledge production / research } \\
\text { Transdisciplinary } \\
\text { - } \quad \text { Knowledge is produced in a context of application } \\
\text { - } \quad \text { Wider definitions of knowledge } \\
\text { - } \quad \text { Heterogeneity of research skills } \\
\text { - } \quad \text { More socially accountable and reflexive than Mode } 1 \\
\text { - } \quad \text { Problem-solving oriented research } \\
\text { - } \quad \text { Expanded system of quality control }\end{array}$ \\
\hline Student-driven: Driven by lecturer's interest & $\begin{array}{l}\text { Client orientation: Dialogue between researchers and users, } \\
\text { regulators, interest groups, etc. }\end{array}$ \\
\hline $\begin{array}{l}\text { Researchers in a "closed" environment - little influence from } \\
\text { outside }\end{array}$ & $\begin{array}{l}\text { Researchers have more interaction with practitioners in the } \\
\text { particular field of interest }\end{array}$ \\
\hline Research reports for a specific target or intellect group & $\begin{array}{l}\text { Research report not necessarily in scientific conferences and } \\
\text { journals but confined to reports closely held by commercial } \\
\text { sponsors }\end{array}$ \\
\hline University-based research & $\begin{array}{l}\text { Research project depend less on funding from central } \\
\text { government or non-profit foundations and more on the firms, } \\
\text { industries and social lobbies directly involved }\end{array}$ \\
\hline Limited sharing of resources and expertise & Sharing of resources with other institutions \\
\hline $\begin{array}{l}\text { Divide between teaching and research with little integration } \\
\text { of the two }\end{array}$ & Focus on the relationship between teaching and research \\
\hline
\end{tabular}

\subsection{The rise of neoliberalism}

In present-day South Africa's social and economic development the outcome of a new-liberal free market policy is combined with and/or restricted by certain government measures. These measures are basically driven by the desire to establish equity and redress the inequalities of the apartheid era (Kampsteeg, 2008). The emergence of quality assurance in discourses on higher education might have been affected by the emergence of an audit culture associated with the rise of neoliberalism (Le Grange, 2011). Ball (2003) mentions that performativity is a mode of regulation that employs judgements and displays as means of incentives, control, attrition and change, based on rewards and sanctions. On the neoliberal agenda the idea of self-regulation is evident through systems of peer auditing, evaluation and review, leading to attainment of self-accreditation status on the part of higher education institutions. This in itself is problematic as self-regulation implies an association with academic freedom and institutional autonomy (Le Grange, 2011). The government has opted to support neo-liberal economic policies, while in the domain of government institutions preferential treatment (black empowerment) is chosen as the major strategy of the social transformation agenda (Kampsteeg, 2008).

Interconnectedness is the idea that the global knowledge economy has influenced the way in which the state funds research publication in South Africa. Universities receive direct state funding by way of subsidy income that is based on teaching inputs, teaching outputs and research outputs and the state only gives research funding, for example, for articles that have been published in accredited journals (Le Grange, 2011). The downside is that one of three accredited lists of journals are owned by Thomson Reuters, a multi-billion USA company meaning that a private company is now indirectly controlling the journals South African academics publish in. If academics choose 
to publish in journals (although they may be the best quality journals) not included on one of these lists, the income that their institutions receive will be reduced. Thus, South African academics and the universities in which they work have not been unaffected by this capitalisation of knowledge (Le Grange, 2011).

\section{CONCLUSION}

More than a decade after the mergers began to take place, issues of access, equity and quality in relation to the core functions of higher education remain challenges in higher education (Le Grange, 2011). It should also be noted that although there is gradual if reluctant acceptance of mergers, it is more giving in to the idea rather than firm belief in the idea. This is an area that necessitates the intervention of strong strategic leadership to build and communicate a picture of the future institution that staff can associate with (Goldman, 2011).

Thus, the restructuring of tertiary education has been a challenging process for all stakeholders. It was much needed and long-overdue, but the challenge that remains is to get it right the first time without compromising standards of academic and socio-economic excellence. Although acknowledging that discrepancies of the legacy of apartheid need to be overcome, the emotive factors in processes of transformation threaten to tip the scale to the wrong side of the academic spectrum. This article cautions stakeholders to objectively investigate the rationale for academic training in institutions of excellence within a post-apartheid system where socio-economic excellence should be accounted for in a way where academic excellence should lead and not follow. It also analysed the background that led to the restructuring and merging of institutions and the implications thereof. It is recommended that further research should be done on the challenges that still exist within tertiary education. It is especially deemed necessary that research should focus on the changing role of academics, socio-economic factors, funding as well as teaching and research grants. Last, but not the least, it is acknowledged that mergers and restructuring of higher institutions were a mechanism intended to overcome socio-economic and infra-structural barriers to higher education, but quality teaching, proper institutional management and administration and high graduate output in relevant fields will remain the qualify forces where the buck will stop.

\section{AUTHOR INFORMATION}

Nelda Mouton, Ph.D., North-West University, South Africa, Manager: Admissions and Records, Private Bag X2046, Mmabatho 2735, South Africa. Email: 10516387@nwu.ac.za (Corresponding author)

Prof. G.P. Louw, Ph.D., Research focus area: Physical activity, sport and recreation. Faculty of Health Sciences, North-West University, South Africa, Private Bag X 2046, Mmabatho 2735, South Africa. Email: 10056394@nwu.ac.za

Prof. G.L. Strydom, Ph.D., School of Biokinetics, Recreation and Sport Science, North-West University, South Africa, Private Bag X6001, Potchefstroom 2520, South Africa. Email: 10172521@ nwu.ac.za

\section{REFERENCES}

1. $\quad$ Anon. (2002, January 29). University merger. Natal Witness, p 8.

2. Ball, S. (2003). The teacher's soul and the terrors of perfomativity. Journal of Education Policy, 18(2), 215-228.

3. Blaine, S. (2010, November 26). University of the Free State has "crossed the Rubicon". Business Day, p 4.

4. Blunt, R.J.S. (2005). Challenges for the curriculum of a comprehensive university: a critical study. South African Journal of Higher Education, 19(6), 1021-1032.

5. Boughey, C. (2004). Higher education in South Africa: context, mission and legislation. In Teaching and learning in higher education. Pretoria: Van Schaik Publishers.

6. $\quad$ Cohen, L. (2006, June 18). Brain drain claims at Merger University. Sunday Argus, p 13.

7. Department of Education (DoE). (2002). Towards a higher education landscape. Available at: http://www.education.pwv.gov.za/DoE_Sites/Higher_Educ/CHE.html.

8. Dill, D. (2009). Convergence and diversity: The role and influence of university rankings. North Carolina: Chapel Hill. 
9. Draai, E. \& Theron, F. (2007). Employment equity at newly merged institutions: The Nelson Mandela Metropolitan University. Journal of Public Administration, 42(2), 105-118.

10. Du Plessis, C. (2011, March 14). Higher knowledge badly needed. The Times, p 6.

11. Du Plessis L. \& Lodewyckx, E. (2007). Crossing the Rubicon in higher education. South African Journal for Higher Education, 21(7), 842-857.

12. Elliott, J. (2005). Merging right: questions of access and merit in South African higher education reform, 1994-2002. Perspectives in Education, 1994-2002. 23(1), 69-76.

13. Eloff, T. (2009). Vice Chancellor's Newsletter. North-West University. March.

14. Gernetzky, K. (2011, May 27). Merger of Medunsa, University of the North to be reversed. Business Day, p 4.

15. Goedegebuure, L. (1992). Mergers in Higher Education. A Comparative Perspective. Utrecht: Lemma.

16. Goldman,G.A. (2011). The effect of institutional predisposition on experiences of a merger. Journal of Contemporary Management, 83, 4-53.

17. Hall, M, \& Symes, A. (2005). South African higher education in the first decade of democracy: from cooperative governance to conditional autonomy. Studies in Higher Education, 30(2), 199-212.

18. Harman, K. \& Meek, V.L. (2002). Introduction to Special Issue: "Merger revisited educational perspectives on mergers in higher education. Higher Education, 44, 1-4

19. Harper, P. (2011, June 26). An honour and a privilege. City Press. Retrieved from http://152.11.1.87/arcihve/citypress/2011/06/27/CP/html.

20. Hay, D. (2000). Quality research in South African higher education: illusions, imperatives and ideals. South African Journal of Higher Education, 14(1), 53-60.

21. Higher Education Act. (1997). Higher Education Act 101. Pretoria: Government Printers.

22. IAIE, see International Alliance for Invitational Education.

23. International Alliance for Invitational Education. (2002). All about invitational education. Available at: http://www.invitationaleducation.net/

24. Jansen, J. (2001). Does the national plan effectively address the critical issues facing higher education? South African Journal of Higher Education, 15(3), 5-9.

25. Jansen, J.D. (2002). Mode 2 knowledge and institutional life: Taking Gibbons on a walk through a South African University, Higher Education, 43, 507-521.

26. Jansen, J.D. (2003). Mergers in South African higher education: Theorizing change in transitional contexts. Politikon, South African Journal of Political Studies, 30(1), 455-469.

27. Jansen, J.D. (2004). How mergers shape the institutional curriculum. South African Journal of Higher Education, 18(1), 5-18.

28. Jansen, J.D. (2005). Mergers in higher education. Lessons learned in transitional contexts. Pretoria: Unisa Press.

29. Jansen, J.D., Habib, A., Gibbon, P. \& Parekh, A. (2001). Accounting for change: the micropolitics of university restructuring. part three: global pressures, local responses. South African Journal for Higher Education, 15(3), 32-38.

30. Kampsteeg, F. (2008). In search of a merged identity: The case of multi-campus North-West University, South Africa. The Journal for Transdisciplinary Research in Southern Africa, 4(2), 431-451.

31. Kgosana, C. \& Mokone, T. (2011, November 3). University 'bankrupt': Minister. The Times, p 2.

32. Khoza, C. (2009, November 18). Pitfalls of supporting access to higher education policy. Daily Dispatch, p 10 .

33. Kraak, A. (2001). Policy Ambiguity and Slippage: Higher education under the new state, 1994-2001. In Kraak, A \& Young, M., eds. Education in Retrospect. Johannesburg: Ultra Litho (Pty) Limited. p 85-120.

34. Kraak, A \& Young, M. (2001). Education in Retrospect. Johannesburg: Ultra Litho (Pty) Limited.

35. Le Grange, L. (2011). (Re)thinking (trans)formation in South African (higher) education. Perspectives in Education, 29(2), 1-9.

36. Macupe, B. (2012, July 29). Poor leadership cripples tertiary institutions. Sunday Independent, p 7.

37. Magome, M. (2009, October 5). TUT looks back after five years since merger. Pretoria News, p 1.

38. Majola, B. (2002, March 15). Tukkies rejects call for reform. Mail and Guardian, p 4.

39. May, T. \& Mason R.B. (2007). Goal clarity and trust in management in educational mergers. Acta Commercii, 7, 151-163. 
40. Metcalfe, A.G. (2008). A response to employment equity policy in a South African University: A case study of an academic mentoring programme. Western Cape: University of the Western Cape. (Mini-dissertation - Master's Degree). 130 p.

41. Mfusi, X.M. (2004). The effects of higher education mergers on the resultant curricula of the combined institutions. South African Journal of Education, 18(1), 98-110.

42. Modjadji, N. (2011, December 12). "Disband Council” says Sasco. Citizen, p 4.

43. Monama, T. (2010, October 8). Varsity merger is not working. Sowetan, p 4.

44. NPHE, see National Plan for Higher Education

45. National Plan for Higher Education. (2001). Ministry of Education. Pretoria. February.

46. Ondari-Okemwa, E. (2011). Knowledge production and distribution by institutions of higher education in sub-Saharan Africa: Opportunities and challenges. South African Journal of Higher Education, 25(7), 1447-1469.

47. Papadakis, V.M. (2005). The role of broader context and the communication program in merger and acquisition implementation success. Management Decision, 43(5), 236-255.

48. Purkey, W.W. \& Schmidt, J.J. (1990). Invitational learning for counselling and development. Ann Arbor, Mich: ERIC Counselling and personnel services clearinghouse.

49. Qhobela, M. (2009, October 15). Why mergers matter. Mail and Guardian, p 4.

50. Ramphele, M. (1994). Equity and Policy: Reality factors and their implications. In Kaplan, B. Changing by degrees? University of Cape Town: UCT Press. p. 18-24.

51. Sangotsha, V. (2008, August 26). Tertiary unions merge to survive. Daily Dispatch, p 4.

52. Schraeder, M \& Self, D.R. (2003). Enhancing the success of mergers and acquisitions: An organizational culture perspective. Management Decision, 41(5), 511-522.

53. Seepe, S. \& Lansink, A. (2010, May 10). Universities must still carve out a responsive role in SA. Business Day, p 11.

54. Sehoole, M.T.C. (2005). The politics of mergers in higher education in South Africa. Higher Education, 50, 159-179.

55. Skiti, S (2011a, 25 December). An education system in crisis. City Press. Retrieved from http://152.111.1.87/archive/citypress/2011/12/24/CP/4/html.

56. Skiti, S (2011b, November 6). Union will fight university lay-offs. City Press. Retrieved from http://152/111/1/87/archive/citypress/2011/11/07/CP/9/html.

57. Tyobeka, E.M. \& Schoeman, G. (2007). Making sense of the merger. Discourse/Diskoers, 35(1), $20-26$.

58. Waghid, Y. (2003). Democracy, higher education transformation and citizenship in South Africa. South African Journal for Higher Education, 17(1), 91-97.

59. Weber, P.S. \& Weber, J.E. (2001). Changes in employee perceptions during organisational change. Leadership and Organisation Development Journal, 22(6), 291-300. 